\title{
Nasilje, šola, družba
}

\author{
Mitja Sardoč \\ Barbara Japelj Pavešić
}

$\mathrm{P}$ reučevanje nasilja $\mathrm{v}$ vzgoji in izobraževanju, kot tudi v družbi nasploh, ima v svetu dolgo tradicijo, saj velja zagotavljanje varnega in spodbudnega učnega okolja za enega od temeljnih načel šolanja. Poleg teoretikov, snovalcev politik ter strokovno-pedagoških delavcev in staršev zagotavljanju varnega in spodbudnega učnega okolja posebno pozornost namenjajo tudi nekatere izmed najpomembnejših globalnih $\gg$ think tank « (npr. Brookings) kot tudi »fact tank « organizacij (npr. Pew Research Centre), v Sloveniji pa je zagotavljanje varnega in spodbudnega učnega okolja že nekaj let prednostna naloga Ministrstva za izobraževanje, znanost in šport.

Kljub temu pa se raziskovanje nasilja $\mathrm{v}$ šolah oz. $\mathrm{v}$ družbi sooča $\mathrm{z}$ vrsto problemov in izzivov, ki pomembno vplivajo tako na sam proces raziskovanja tega fenomena kakor tudi na snovanje predlogov za zagotavljanje varnega in spodbudnega učnega okolja. Zaradi vse večje prisotnosti nasilja $\mathrm{v}$ družbi in njegove pojavnosti, skoraj »glorifikacije « v medijih, ki jo najbolje ponazarja prispodoba $\mathrm{o} \gg$ simbiotičnem « razmerju medijev in nasilja, zaradi številnih novih pojavnih oblik nasilja, kot je »kibernetsko « nasilje predvsem med mladimi, je za preučevanje tega družbenega fenomena nujna interdisciplinarnost, ki zagotovi razumevanje nasilja izven njegovih »tradicionalnih « okvirov. Iskanje skupnega imenovalca različnih pojavnih oblik nasilja pa se izkaže za vse prej kot enostavno, saj je tudi nasilje $\mathrm{v}$ šolah in med šolajočo mladino - tako v teoriji kakor tudi $\mathrm{v} \gg$ praksi « kompleksen fenomen $\mathrm{z}$ mnogimi prikritimi dejstvi in povezavami z osebnim dogajanjem mladim v družbi izven območja izobraževanja. Pri tem 
izrazito izstopa nasilje, ki so ga mladi lahko deležni preko interakcij s svetovnim spletom.

V drugem delu tematske številke revije smo zbrali članke, ki prinašajo vpogled $\mathrm{v}$ konkretno stanje problematike $\mathrm{v}$ izobraževanju. Razprave o empiričnih raziskavah dopolnjujejo strokovni pregledi aktivnosti za preprečevanje nasilja, ki se že izvajajo v našem prostoru.

Prispevek Psihološki vidiki medvrstniškega nasilja $v$ šlah: ugotovitve nekaterih slovenskih raziskav dr. Sonje Pečjak in dr. Tine Pirc prikazuje psihološko raziskovanje različnih vidikov medvrstniškega nasilja na šolah, $\mathrm{z}$ opisom lastnih raziskovalnih rezultatov $\mathrm{s}$ tega področja $\mathrm{v}$ preteklih letih, ki kažejo, da je tega nasilja pomembno več v osnovni kot srednji šoli, več med fanti kot dekleti in več med učno manj uspešnimi učenci. Zagrebški avtorji mag. Marko Prpić, dr. Jelena Pavičić Vukičević in mag. Matea Korda v prispevku Šolska klima kot napovedovalec nasilja učencev nad učitelji predstavljajo inovativno raziskavo merjenja poročanja učencev in hkrati učiteljev o pojavu nasilja nad učitelji ter ugotavljajo dejavnike, ki določene vrste nasilja nad učitelji najbolj napovedujejo. Članek Doživljanje nasilja $v$ mladostništvu: vloga odnosov z vrstniki, odnosov $z$ učitelji ter čustvenih in socialnih kompetenc avtoric Tine Pivec in dr. Ane Kozina predstavlja glavna sporočila raziskovanja napovedne vrednosti dejavnikov čustvenih in socialnih kompetenc, vrstniških odnosov in odnosov učencev z učitelji za pojav viktimizacije v okviru projekta Roka v roki: Socialne in čustvene spretnosti za nediskriminatorno in vključujočo skupnost, ki sporočajo, da so bistveni dobri odnosi z učitelji, saj so ključni napovedniki viktimizacije pozitivni odnosi z vrstniki in negativni odnosi z učitelji, ki tudi vplivajo na povezanost viktimizacije $s$ prosocialnim vedenjem ter z negativnimi odnosi z vrstniki. Rezultati analize povezanosti med pripadnostjo šoli, doživetim nasiljem, motivacijo za učenje in znanjem na podlagi nacionalnih podatkov merjenja stališč in znanja osnovnošolcev v prispevku Ali je šolsko nasilje med slovenskimi učenci povezano z učenjem? kažejo, da so različne oblike nasilja povezane $\mathrm{z}$ uspešnostjo različno starih učencev v šoli in opozarjajo še posebej na tiste kritične oblike nasilja za otroke, ki lahko ostanejo med odraslimi neopažene zaradi njihovega manjšega pomena v odraslem svetu.

$\mathrm{V}$ prispevku Spletno nadlegovanje v šolah $z$ vidika spola dr. Barbara Neža Brečko razpravlja o svežih rezultatih pravkar zaključene velike nacionalne raziskave Odklikni! o spletnem nasilju nad dekleti, ki je v Sloveniji ne samo v porastu, ampak je tudi že doseglo kritično raven. Vsebinsko širok pregledni strokovni članek Maje Vreča Spletno nasilje, virtualno nasilje ali nasilje, ki uporablja nove tehnologije? nam predstavi izhodiščne okvire in širino strokovnih aktivnosti akademskih ter zasebnih združenj 
na nacionalni ravni za preventivno in pomoč pri pojavih spletnega nasilja med šolajočo se mladino.

V prispevku Preventivna vloga pozitivnih psihosocialnih odnosov $v$ šoli nam dr. Zora Ilc Rutar predstavi pomembnost odnosne kompetence učiteljev ter odnosa med učitelji in učenci za doseganje optimalne šolske in razredne klime, ko, izhajajoč iz teoretskih izhodišč, predstavi konkretne nacionalne vire in aktivnosti za zagotavljanje spodbudnega šolskega okolja in preprečevanja nasilja. Predstavitev učinkovitih aktivnosti za prevencijo nasilja in spodbujanje pozitivne šolske klime zaokrožuje prispevek Martine Kukovec o vzpostavitvi in analizi učinkovitosti vrstniške mediacije v šolskem prostoru, ki se pokaže uspešna tako kot vzgoja za mediatorje kot za izboljšanje šolske klime.

Prispevke tako družijo skupne ugotovitve o pomembnosti zavedanja o nasilju v vseh oblikah, pomembnosti kakovostnega odnosa med vsemi člani šolske skupnosti ter o vlogi in pomenu zagotavljanja varnega in spodbudnega učnega okolja. 